\title{
Faktor Penyebab dan Upaya Penanggulangan Tindak Pidana Pengalihan Objek Jaminan Fidusia
}

\author{
M. Hadhri Nur, Elly Sudarty, Dheny Wahyudhi
}

Fakultas Hukum Universitas Jambi

Author's Email Correspondence: Hadhrinur@gmail.com

\section{ABSTRAK}

Penelitian ini bertujuan 1) untuk mengetahui dan menganalisis faktor penyebab terjadinya terjadinya tindak pidana pengalihan objek jaminan fidusia di Kota Jambi; 2) untuk mengetahui dan menganalisis upaya penanggulangan terjadinya tindak pidana pengalihan objek jaminan fidusia di Kota Jambi. Metode penelitian yang digunakan adalah metode penelitian hukum empiris. Hasil penelitian menunjukkan bahwa 1) faktor-faktor penyebab terjadinya tindak pidana pengalihan objek jaminan fidusia di Kota Jambi terdiri atas faktor internal, dan faktor eksternal. ; 2). upaya penanggulangan penyebab terjadinya tindak pidana pengalihan objek jaminan fidusia di Kota Jambi adalah dengan upaya preventif maupun represif dari pihak kepolisian dan pihak terkait dengan jaminan fidusia.

\section{ARTICLE HISTORY}

Submission: 2020-11-19

Accepted: 2020-12-02

Publish: 2020-12-02

KEYWORDS: Causative Factor; countermeasures; crime diversion objects fiduciary.
Kata Kunci: Faktor

penyebab; upaya penanggulangan; tindak pidana pengalihan objek jaminan fidusia.

\begin{abstract}
This study aims 1) to determine and analyze the factors causing the occurrence of the crime of transferring the object of fiduciary security in Jambi City; 2) to identify and analyze efforts to overcome the occurrence of a criminal act of transferring the object of fiduciary security in Jambi City. The research method used is empirical legal research methods. The results showed that 1) the factors causing the crime of transferring the object of fiduciary security in Jambi City consisted of internal factors and external factors. ; 2). Efforts to overcome the cause of the crime of transferring the object of fiduciary security in Jambi City are through preventive and repressive measures from the police and related parties with fiduciary guarantees.
\end{abstract}

\section{A. PENDAHULUAN}

Lembaga pembiayaan adalah salah satu bentuk usaha dibidang lembaga keuangan non Bank yang mempunyai peranan sangat penting dalam pembiayaan dan pengelolaan salah satu sumber dana pembangunan di Indonesia. Kegiatan lembaga pembiayaan dilakukan dalam bentuk penyediaan dan/atau barang modal serta barang kebutuhan konsumen dengan tidak menarik dana secara langsung dari masyarakat melalui deposito, tabungan, giro dan surat sanggup bayar.

Dalam Keputusan Menteri Keuangan RI No. 448/KMK.017/2000, Tentang Perusahaan Pembiayaan diperincikan bahwa kegiatan lembaga pembiayaan meliputi:

a. Sewa Guna Usaha,

b. Modal Ventura, 
c. Perdagangan Surat Berharga,

d. Anjak Piutang,

e. Usaha kartu Kredit, dan

f. Pembiayaan Konsumen.

Pembiayaan Konsumen (Consumer Finance) berdasarkan Pasal 1 Ayat (7) Peraturan Presiden Nomor 9 Tahun 2009 menyatakan "pembiayaan konsumen adalah kegiatan pembiayaan untuk pengadaan barang berdasarkan kebutuhan konsumen dengan pembayaran secara angsuran".

Bisnis pembiayaan konsumen menarik minat banyak masyarakat, sebab biasanya konsumen akan sulit mendapatkan atau mempunyai akses untuk mendapatkan kredit bank. Bisnis pembiayaan konsumen ini diharapkan akan terus berkembang. Ada beberapa alasan debitur mempergunakan fasilitas pembiayaan konsumen yaitu:

a. Tidak terlalu banyak persyaratan dibandingkan dengan sumber pembiayaan lainnya

b. Tidak berorientasi pada jaminan (noncollateral basis)

c. Tidak mengganggu keuangan konsumen karena membutuhkan dana yang relatif kecil

d. Cepat pemprosesannya

e. Pembayaran angsuran dapat dibayar melalui anggaran rutin bulanan konsumen dari pendapatan yang diterima

f. Angsuran dapat disesuaikan dengan kemampuan konsumen

g. Penyesuaian terhadap mata uang berdasarkan pendapatan yang diterima

h. Pembayaran angsurannya tetap sehingga memudahkanpengaturan pengelolaan keuangan debitur. ${ }^{1}$

Dalam pelaksanaan pembiayaan konsumen antara debitur dan kreditur, tentunya tidak menutup kemungkinan tidak terlaksana dengan baik dan benar sesuai dengan yang diperjanjikan. Permasalahan tersebut bisa saja timbul di antara para pihak baik itu kreditur maupun debitur.

Aktivitas pengalihan utang merupakan kegiatan yang dilakukan debitur dalam usahanya untuk pengalihan kewajiban pembayaran utang atau kreditnya kepada pihak lain, tetapi tanpa sepengetahuan atau melibatkan perusahaan pembiayaan konsumen. Hal ini tentu saja dikategorikan sebagai perbuatan yang melanggar hukum bahkan masuk kedalam kategori tindak pidana. Sebab mobil yang digunakan merupakan jaminan utang debitur pada perusahaan pembiayaan konsumen.

Perbuatan pengalihan utang tanpa persetujuan tertulis dari penerima fidusia terhadap objek jaminan fidusia dari perusahaan pembiayaan konsumen, diatur secara tegas dalam Pasal 23 Ayat (2) Undang-Undang Nomor 42 tahun 1999 Tentang Jaminan Fidusia yaitu:

"pemberi fidusia dilarang pengalihan, menggadaikan, atau menyewakan kepada pihak lain benda yang menjadi objek jaminan fidusia yang tidak merupakan benda persediaan, kecuali dengan persetujuan tertulis terlebih dahulu dari penerima fidusia". Perbuatan pengalihan utang terhadap objek jaminan fidusia tanpa sepengetahuan sipenerima fidusia merupakan sebuah tindak pidana sebagaimana diatur dalam Pasal 36 Undang-Undang Nomor 42 tahun 1999

1 Budi Rachmat, Multi Finance Handbook, Pradya Paramita, Jakarta, 2004, hlm. 188 
Tentang Jaminan Fidusia yaitu: "pemberi fidusia dilarang pengalihan, menggadaikan atau menyewakan benda yang menjadi objek jaminan fidusia sebagaimana dimaksud dalam Pasal 23 Ayat (2) yang dilakukan tanpa pesetujuan tertulis terlebih dahulu dari penerima fidusia, dipidana dengan pidana penjara paling lama 2 (dua) tahun dan denda paling banyak Rp. 50.000.000,. (lima puluh juta) rupiah".

Dalam tiga tahun terakhir diwilayah hukum Polresta Jambi, tindak pidana tersebut selalu saja terjadi sebagaimana terlihat pada tabel di bawah ini.

\section{Tabel 1}

Jumlah Kasus Tindak Pidana Pengalihan Objek Jaminan Fidusia

Berupa Kendaraan Roda 4 (Mobil) Tahun 2018-2020 di Polresta Jambi

\begin{tabular}{|c|c|c|c|c|}
\hline No & Tahun & Pelapor & Kasus & Jumlah Kasus \\
\hline \multirow[t]{3}{*}{1} & 2018 & ACC & 5 & \multirow[t]{3}{*}{10} \\
\hline & & $\begin{array}{l}\text { Toyota } \\
\text { Finance }\end{array}$ & 3 & \\
\hline & & Adira Finance & 2 & \\
\hline \multirow[t]{3}{*}{2} & 2019 & ACC & 8 & \multirow[t]{3}{*}{15} \\
\hline & & $\begin{array}{c}\text { Toyota } \\
\text { Finance }\end{array}$ & 4 & \\
\hline & & Adira Finance & 3 & \\
\hline \multirow[t]{3}{*}{3} & 2020 & ACC & 9 & \multirow[t]{3}{*}{12} \\
\hline & & Toyota & 2 & \\
\hline & & Adira Finance & 1 & \\
\hline
\end{tabular}

Sumber Data: Polresta Jambi

Pada tabel tersebut di atas terlihat bahwa dalam tiga tahun belakang ini, jumlah kasus tindakan pengalihan, menggadaikan atau menyewakan benda yang menjadi objekjaminan fidusia yang dilakukan tanpa persetujuan tertulis terlebih dahulu dari penerima fidusia ke Polresta Jambi adalah sebanyak 37 (tiga puluh) tujuh kasus, dengan rincian 10 (sepuluh) kasus tahun 2018, 15 (lima belas) kasus tahun 2019, dan 12 (dua belas) kasus tahun 2020,. Jumlah kasus terbanyak adalah di PT. Astra Credit Companies Kota Jambi yang setiap tahunnya mengalami peningkatan terhadap tindak pidana pengalihan objek jaminan fidusia yang dilakukan oleh debiturnya. Di PT. Astra Credit Companies sendiri selama tahun 2020 ada 20 debitur yang melakukan tindak pidana pengalihan objek jaminan fidusia tanpa persetujuan dari penerima fidusia yang kemudian kedepannya terjadi permasalahan dimana ketika terjadi macet pembayaran pihak penerima fidusia ingin mengeksekusi mobil tersebut ternyata sudah tidak ada. 
Salah satu perusahaan yang bergerak dalam pemberian jasa pelayanan pembiayaan kepada konsumen adalah PT. Astra Credit Companies (ACC) Cabang Jambi, yang berkantor pusat di Jakarta yang bergerak dalam usaha pembiayaan pembelian kendaraan dan lain-lain.

Berdasarkan uraian di atas, maka penulis tertarik untuk mengadakan penelitian dan penulisan dalam rangka penyusunan skripsi dengan judul "Faktor Penyebab dan Upaya Penanggulangan Tindak Pidana Pengalihan Objek Jaminan Fidusia Kota Jambi".

\section{B. METODE PENELITIAN}

Tipe penelitian ini adalah yuridis empiris, penelitian ini bertujuan untuk memperoleh data tentang: 1) faktor-faktor penyebab terjadinya tindak pidana pengalihan objek jaminan fidusia di Kota Jambi terdiri atas faktor intern yaitu faktor kurangnya kesadaran dalam diri pelaku, pelaku yang terkesan mengabaikan isi perjanjian jaminan fidusia, dan faktor ekstern yaitu tekanan ekonomi, faktor lingkungan (penadah), kurangnya pengawasan dari pihak korban. ; 2). upaya penanggulangan penyebab terjadinya tindak pidana pengalihan objek jaminan fidusia di Kota Jambi adalah dengan preventif dari pihak kepolisian yaitu melakukan sosialisasi kepada pihak pembiayaan konsumen untuk mendaftarkan objek jaminan fidusia bekerjasama dengan Otoritas Jasa Keuangan dan Kanwil Kemenkumham kemudian dari pihak korban yaitu ditingkatkan pengawasan terhadap konsumen yang menunggak, menambah jumlah eksekutor, mendaftarkan dan membuat akta jaminan fidusia, bekerjasama dengan pihak kepolisian untuk melakukan sosialisasi kemasyarakat. Sedangkan upaya represif yang dilakukan Polresta Jambi yaitu Menerima laporan dan berusaha mencari jalan terbaik dengan keadilan restoratif dan upaya represif dari pihak korban yaitu Melakukan beberapa tindakan dari SP 1 sampai SP 3 dan somasi. Jika tidak ada kata sepakat maka berlanjut ke jalur hukum.

\section{PEMBAHASAN}

\section{Faktor Penyebab Terjadinya Tindak Pidana Pengalihan Objek} Jaminan Fidusia di Kota Jambi

Tindak pidana pengalihan objek jaminan fidusia dapat disebabkan berbagai faktor dari pelaku tindak pidana pasal tersebut (debitur). Faktor-faktor tersebut ada yang bersifat ekstern dan ada yang bersifat intern.

Di PT. Astra Credit Companies sendiri setiap tahunnya sering terjadi tindak pidana pengalihan objek jaminan fidusia tanpa persetujuan dari penerima fidusia yang kemudian kedepannya terjadi permasalahan dimana ketika terjadi macet pembayaran pihak penerima fidusia ingin mengeksekusi mobil tersebut ternyata sudah tidak ada.

Adapun faktor penyebab terjadinya tindak pidana pidana pengalihan objek jaminan fidusia, dapat dikemukakan sebagai berikut:

1. Faktor Intern

Secara umum, faktor penyebab terjadinya tindak pidana pengalihan objek jaminan fidusia yang berasal dari dalam diri pelaku adalah:

a. Faktor Kurangnya Kesadaran dalam Diri Pelaku

Mengenai faktor kurangnya kesadaran dalam diri pelaku Yoyok Subandri mengatakan bahwa "Saya tidak menyadari bahwa perbuatan pengalihan objek jaminan fidusia tersebut merupakan tindak pidana karena banyak orang juga yang melakukan hal yang sama seperti saya dan tidak tersandung masalah hukum". ${ }^{2}$ Berdasarkan hasil wawancara yang dilakukan 
oleh penulis terhadap responden atau pelaku tindak pidana tersebut didapatkan bahwa pelaku cendrung abai dan tidak menyadari bahwa perbuatan yang dilakukan adalah kejahtan dan termasuk dalam tindak pidana seperti yang dijelaskan dalam ketentuan Pasal 23 Jo Pasal 36 UndangUndang Fidusia, padahal perbuatan tersebut tanpa disadari pelaku merupakan suatu perbuatan yang dapat dipidana dan dapat diancam dengan pidana penjara paling lama 2 (dua) tahun dan denda maksimal Rp. 50.000.000,. (Lima Puluh Juta Rupiah).

b. Pelaku cenderung mengabaikan isi perjanjian

Berdasarkan isi perjanjian jaminan fidusia antara kreditur dan debitur, debitur dilarang pengalihan objek jaminan fidusia tanpa persetujuan dari kreditur, hal ini juga senada dengan apa yang diatur dalam ketentuan Pasal 23 Undang-Undang Fidusia. Dari hasil wawancara yang dilakukan oleh penulis, semua debitur/pelaku tindak pidana tersebut mengabaikan isi perjanjian jaminan fidusia yang dibuat para pihak. Para debitur meskipun telah mengetahui bahwasanya objek jaminan fidusia tidak boleh dialihkan namun para debitur terkesan mengabaikan dan tetap pengalihan objek jaminan fidusia tersebut kepada pihak ketiga tanpa persetujuanpihak kreditur.

Peristiwa-peristiwa di bawah ini merupakan cidera janji debitur dalam melaksanakan perjanjian ini, tanpa perlu didahului dengan surat peringatan khusus atau suatu penetapan dari pengadilan melainkan cukup telah terbukti dengan:

1. Debitur tidak membayar angsuran, denda dan biaya-biaya lain atas suatu jumlah yang telah jatuh tempo sesuai perjanjian, yang dalam hal lewatnya waktu saja telah memberi bukti yang cukup bahwa debitur telah melalaikan kewajibannya menurut perjanjian ini, sehingga peringatan dengan juru sita atau surat-surat lain serupa itu tidak diperlukan lagi.

2. Barang yang dijual, disewakan, dipindah tangankan, dialihkan atau dijaminkan kepada pihak ketiga tanpa mendapat persetujuan tertulis terlebih dahulu dari kreditur.

3. Apabila suatu pernyataan, surat keterangan atau dokumen- dokumen yang diberikan oleh debitur dan/atau pemilik jaminan sehubungan dengan perjanjian ini ternyata tidak beanar /palsu. Debitur dan/atau pemilik jaminan tidak melaksanakan kewajiban atau lalai untuk memenuhi syarat-syarat dan ketentuan-ketentuan dalam perjanjian. ${ }^{2}$

Mengenai faktor mengabaikan isi perjanjian, salah satu debitur yakni bapak Muchtar Pakpahan mengatakan Saya tau bahwa perbuatan tersebut tidak boleh dilakukan tapi karena saya membutuhkan uang jadi saya terpaksa melakukannya hal ini juga didukung dengan adanya pihak ketiga yang mau menerima pengalihan objek jaminan fidusia yang tidak mempertanyakan mengenai status barang tersebut.

Selanjutnya dari wawancara dengan informan Fajar Kuncoro mengatakan "Faktor-faktor yang menjadi penyebab terjadinya tindak pidana

2 Perjanjian Pembiayaan Konsumen No. 01-022-06-02426, PT Astra Credit Companies (ACC) Cabang Jambi, 2018, hlm. 3 
pengalihan objek jaminan fidusia, pertama karena ekonomi, kedua karena kepura ketidaktahuan pelaku bahwa perbuatan itu tindak pidana".

Dari hasil wawancara dengan bapak muchtar dan fajar kuncoro, penulis dapat menyimpulkan bahwa adanya kesesuaian fakta dilapangan mengenai faktor penyebab tindak pidana pengalihan objek jaminan fidusia yakni debitur mengabaikan isi perjanjian jaminan fidusia yang telah dibuat antara pihak debitur dan kreditur.

\section{Faktor Ekstern}

Faktor ekstern merupakan faktor yang berasal dari luar yang tercakup dalam faktor lingkungan seperti lingkungan keluarga, masyarakat, geografis dan fasilitas yang ada di dalamnya seperti: makanan, kesempatan, belajar danlainnya.

Faktor-faktor eksternal yang mendorong terjadinya tindak pidanapengalihan objek jaminan fidusia di Kota Jambi, adalah:

a. Tekanan Ekonomi

Keadaan perekonomian yang serba sulit menyebabkan harga kebutuhan hidup terus meningkat. Keadaan ini membuat masyarakat kesulitan karena pendapatan yang diperoleh terkadang tidak sesuai dengan kebutuhan yang semakin meningkat. Sementara kebutuhan hidup keluarga, anak dan istri harus tetap terpenuhi. Perubahan keadaan ekonomi tentunya akan sangat mempengaruhi kehidupan masyarakat. Kondisi perekonomian yang tidak stabil dan terus meningkatnya kebutuhan pokok menyebabkan masyarakat tertekan sehingga mudah melakukan kejahatan. Bagi masyarakat yang dalam kondisi ekonomi yang sulit meminjam uang/hutang menjadi solusi yang aman untuk sementara bagi mereka. Menurut pihak korban yang dalam hal ini dikatakanYura selaku collector PT. ACC Tbk, bahwa: Rata- rata yang melakukan tindak pidana pengalihan objek jaminan fidusia di PT. ACC Tbk adalah mereka yang terlilit masalah hutang piutang. Mereka terpaksa menjual atau menggadaikan kendaraan roda empat untuk membayar hutang dan memenuhi kebutuhan hidup keluarga.

Hal senada juga dikatakan oleh Yoyok Subandri pelaku/debitur yang melakukan tindak pidana terhadap objek jaminan fidusia ini, dia mengatakan bahwa Saya terpaksa menjual mobil tanpa sepengetahuan pihak leasing karena himpitan ekonomi, saya memiliki banyak utang dengan orang sedangkan pendapatan saya pas-pasan. Jika saya jual mobil itu ke orang lain melalui leasing maka syaratnya rumit oleh karena itu saya jual mobil tersebut ke orang lain tanpa sepengetahuan pihak leasing.

Berdasarkan paparan diatas menurut penulis faktor ekonomi merupakan faktor yang paling rentan orang untuk melakukan tindak pidana

b. Faktor Lingkungan Dengan Adanya Penadah

Penyebab terjadinya kejahatan adalah lingkungan. Lingkungan merupakan keseluruhan dari kondisi maupun benda yang ditempah manusia dan yang mempengaruhi seluruh kehidupannya. Dengan demikian dapatlah dikatakan bahwa lingkungan tersebut merupakan segala sesuatu yang ada di sekeliling manusia, baik yang bersifat material maupun immaterial dan juga yang hidup maupun yang tidak hidup. Semua hal-hal tersebut mempengaruhi kehidupan manusia dan dipengaruhi oleh manusia. Adanya faktor 
lingkungan yang dapat mendukung terlaksananya tindak pidana pengalihan objek jaminan fidusia di Kota Jambi adalah Faktor adanya penadah.

Penadah adalah orang yang menampung kendaraan roda empat kredit yang belum lunas pembayarannya. Penadah di sini adalah orang yang menerima gadai atau menerima penjualan barang yang berasal dari hasilkejahatan. Menurut pihak korban yang dalam hal ini dikatakan Yura Collector PT. Astra mengatakan bahwa "konsumen/pelaku menjual mobil tanpa sepengetahuan kami kepada penadah dengan harga murah karena kondisi yang mendesak dan tidak mau ribet".

Menurut penulis pelaku tindak pidana pengalihan objek jaminan fidusia di Kota Jambi, menjual atau menggadaikan kendaraan roda empat kredit tersebut kepada penadah dengan harga yang lebih murah karena kondisi yang mendesak dan tidak mau ribet.

c. Faktor Kurangnya pengawasan dari pihak korban ( PT. ACC Kota Jambi)

Menurut pihak korban yang dalam hal ini dikatakan Yura Collector PT. ACC mengatakan bahwa "Pihak perusahaan mengetahui objek itu dialihkan kepada pihak ketiga setelah adanya permasalahan kredit macet pada saat benda itu ingin dieksekusi objek tersebut sudah dialihkan kepada pihak ketiga".

Dari beberapa kasus pengalihan objek jaminan fidusia hampir seluruhnya diketahui oleh korban pada saat terjadinya kredit macet. Pada saat hendak dieksekusi ternyata objek jaminan fidusia itu telah dialihkan kepada pihak ketiga tanpa sepengetahuan dan persetujuan dari pihak kreditur.

Penulis berpendapat apabila tidak terjadi kredit macet maka pihak kreditur (PT. ACC) tidak akan mengetahui bahwasanya objek jaminan fidusia telah dialihkan oleh pihak ketiga hal ini membuktikan bahwa tidak adanya pengawasan atau lemahnya pengawasan terhadap objek jaminan fidusia oleh pihak kreditur (PT.ACC) hal ini berdampak pengalihan objek jaminan fidusia ke pihak ketiga sering terjadi. Maka dari itu pengawasan dari kerditur sangat penting terhadap pengalihan objek jaminan fidusia kepada pihak ketiga.

Perkembangan kasus yang pernah terjadi, seperti dikemukakan sebagai berikut :

1. Ronald Siagian

Ronald Siagian, 38 tahun, mengambil mobil merk Toyota Kijang Innova. Ronald Siagian mengemukakan bahwa: "Angsuran baru jalan 5 bulan, saya melakukan over alih ke orang lain atas nama Abdullah Saidi. Pengalihan utang ini memang tanpa sepengetahuan pihak PT. Astra Credit Companies Kota Jambi". 10

Ternyata Abdullah Saidi, adalah mafia leasing, mobil Ronald Siagian oleh Abdullah Saidi jual lagi ke orang lain. Sampai sekarang mobil itu belum ditemukan. Pihak PT. Astra Credit Companies Kota Jambi menuntut Ronald Siagian lewat jalur hukum dengan asas fidusia.

2. Muchtar Pakpahan

Muchtar Pakpahan, 43 tahun, mengambil mobil merk Toyota Etiosnya. Muchtar Pakpahan mengemukakan: "Beberapa bulan lalu, saya 
menjual mobil Etios tersebut secara overkredit di bawah tangan, untuk selanjutnya saya beli LCGC menggunakan perusahaan pembiayaan konsumen yang sama yaitu PT. Astra Credit Companies Kota Jambi"11.

Pembeli Etios tersebut ternyata tidak membayar cicilan, jadilah PT. Astra Credit Companies Kota Jambi mulai mendatangi dan menagih pembayaran angsuran yang tertunggak keluarganya. Akhirnya sekarang Etios mau ditarik.

3. Wulandari

Wulandari, 32 tahun, mengambil mobil merk agya kemudian melakukan overalih secara tidak resmi kepada pihak ketiga yang bernama Agus di daerah Tempino, rupanya pihak ketiga macet dalam melakukan pembayaran. Saat ini kasus masih dalam proses.

4. Juanita Violasari

Juanita, 28 tahun, mengambil mobil sigra. Kemudian mobil dioper alih ke daerah Sarolangun dan pembayaran oleh pihak ketiga macet dan pihak finance melakukan prosedur mulai dari SP 1 sampe 3 dan somasi ke debitur serta akan ditindak lanjutkan ke ranah hukum pidana.

5. Yoyok Subandri

Yoyok Subandri, 41 tahun, mengemukakan: "saya mengambil mobil merk Daihatsu Xenia. Karena hutang piutang mobil tersebut saya over alihkan ke orang lain. Tidak tahunya mobilnya dijual ke luar Jambi".12 Sekarang pembayaran macet dari pihak ketiga oleh karena saat ini pihak finance sedang melakukan pelacakan terhadap mobil tersebut dan melakukan somasi kepada debitur.

Berdasarkan perkembangan kasus diatas dapat disimpulkan bahwa debitur melakukan peralihan objek jaminan fidusia tanpa persetujuan dari penerima fidusia dan kemudian terjadi permasalahan dimana ketika pembayaran macet dan pihak penerima fidusia ingin melakukan eksekusi objek jaminan fidusia tersebut sudah tidak ada.

Pengalihan objek jaminan fidusia tanpa persetujuan pihak kreditur tentu merupakan perbuatan yang melanggar hukum menurut pihak korban yang dalam hal ini dikatakan Dova Kalanik, Brach manager PT. Astra Credit Companies (ACC) Finance Cabang Jambi, mengemukakan:

Pengalihan objek jaminan fidusia oleh pihak debitur tanpa persetujuan kreditur dalam peraturan perusahaan tidak diakui, karena tidak dilaksanakan secara resmi. Pihak yang menerima pengalihan utang tidak diakui sebagai debitur kami. Sehingga jika terjadi permasalahan pihak debitur harus bertanggung jawab secara hukum.

Menurut pihak korban Yura Collector ACC Jambi mengatakan sebenarnya pihak finance selalu menjebatani jika debitur ingin mengover alihkan objek jaminan fidusia itu karena jika pengalihan itu dilakukan secara resmi maka pihak debitur akan mendapat perlindungan hukum jika suatu saat terjadi permasalahan. Tentu 
pengalihan objek jaminan fidusia tanpa sepengetahuan kami menimbulkan efek yang buruk buat debitur karena namanya akan cacat dan jika terjadi suatu permasalahan dikemudian hari pihak debitur orang yang harus bertanggung jawab.

Menurut Yura "faktor mereka melakukan pengalihan tanpa sepengetahuan si penerima fidusia karena faktor ekonomi, faktor adanya penadah, dan faktor mendesak karena jika pengalihan secara resmi banyak syarat-syarat administrasi yang harus dipenuhi oleh pihak debitur".

Sebenarnya mobil yang masih dalam tahap angsuran (masih berjalan proses cicilan) dinamakan barang fidusia yang artinya meskipun secara pembayaran dan kepemilikan legalitas secara tertulis namun sebetulnya di mata hukum barang tersebut masih milik perusahaan PT. Astra Credit Companies Kota Jambi. Pendek kata, barang fidusia (hukum fidusia) adalah properti kepemilikan seseorang yang secara hukum masih dimiliki oleh perorangan/perusahaan namun barang/properti tersebut sudah berada di tangan konsumen.

Berdasarkan perkembangan kasus diatas menurut penulis Perbuatan pengalihan objek jaminan fidusia tanpa persetujuan tertulis dari penerima fidusia, dikategorikan sebagai suatu tindak pidana yang diatur secara tegas dalam Pasal 23 ayat (2) Undang-Undang Nomor 42 tahun 1999 Tentang Jaminan Fidusia yaitu: "pemberi fidusia dilarang pengalihan, menggadaikan, atau menyewakan kepada pihak lain benda yang menjadi objek jaminan fidusia yang tidak merupakan benda persediaan, kecuali dengan persetujuan tertulis terlebih dahulu dari penerima fidusia". Perbuatan pengalihan utang terhadap objek jaminan fidusia tanpa sepengetahuan sipenerima fidusia merupakan sebuah tindak pidana sebagaimana diatur dalam Pasal 36 Undang-Undang Nomor 42 tahun 1999 Tentang Jaminan Fidusia yaitu: "pemberi fidusia dilarang pengalihan, menggadaikan atau menyewakan benda yang menjadi objek jaminan fidusia sebagaimana dimaksud dalam Pasal 23 ayat (2) yang dilakukan tanpa pesetujuan tertulis terlebih dahulu dari penerima fidusia, dipidana dengan pidana penjara paling lama 2 (dua) tahun dan denda paling banyak Rp. 50.000.000,. (lima puluh juta) rupiah.

Berdasarkan hasil penelitian didapat suatu gambaran mengenai faktor-faktor penyebab tindak pidana pengalihan objek jaminan fidusia. Hal ini dapat dilihat pada tabel berikut:

Berdasarkan tabel di bawah, dapat dilihat adanya faktor internal dan eksternal yang menjadi penyebab terjadinya tindak pidana pengalihan objek jaminan fidusia di Kota Jambi.

Tabel. 2 
Faktor Penyebab Terjadinya tindak pidana pengalihan objek jaminan fidusia di Kota Jambi

\begin{tabular}{|c|c|c|c|c|c|c|}
\hline \multirow[t]{3}{*}{ No. } & \multirow[t]{3}{*}{ Responden } & \multicolumn{5}{|c|}{$\begin{array}{c}\text { Faktor-Faktor } \\
\text { Penyebab }\end{array}$} \\
\hline & & \multicolumn{2}{|c|}{$\begin{array}{c}\text { Interna } \\
1\end{array}$} & \multicolumn{3}{|c|}{$\begin{array}{c}\text { Eksterna } \\
1\end{array}$} \\
\hline & & $\begin{array}{c}\text { Kurangny } \\
\text { a } \\
\text { kesadara } \\
\text { n dalam } \\
\text { diri } \\
\text { pelaku }\end{array}$ & $\begin{array}{l}\text { Pelaku } \\
\text { terkesan } \\
\text { mengabaika } \\
\mathrm{n} \quad \\
\quad \text { isi } \\
\text { perjanjian }\end{array}$ & $\begin{array}{l}\text { Lingkunga } \\
\mathrm{n} \\
\text { (Penadah) }\end{array}$ & $\begin{array}{c}\text { Tekanan } \\
\text { kebutuha } \\
n \\
\text { Ekonomi }\end{array}$ & $\begin{array}{l}\text { Kurangnya } \\
\text { pengawasa } \\
\text { n dari } \\
\text { pihak } \\
\text { kreditur }\end{array}$ \\
\hline 1. & $\begin{array}{l}\text { Ronald } \\
\text { Siagian }\end{array}$ & $\sqrt{ }$ & $\sqrt{ }$ & $\sqrt{ }$ & $\sqrt{ }$ & $\sqrt{ }$ \\
\hline 2. & $\begin{array}{l}\text { Muchtar } \\
\text { Pakpahan }\end{array}$ & $\sqrt{ }$ & $\sqrt{ }$ & $\sqrt{ }$ & $\sqrt{ }$ & $\sqrt{ }$ \\
\hline 3. & Wulandari & - & $\sqrt{ }$ & $\sqrt{ }$ & $\sqrt{ }$ & $\sqrt{ }$ \\
\hline 4. & $\begin{array}{l}\text { Juanita } \\
\text { Violasari }\end{array}$ & $\sqrt{ }$ & $\sqrt{ }$ & $\sqrt{ }$ & - & $\sqrt{ }$ \\
\hline 5. & $\begin{array}{l}\text { Yoyok } \\
\text { Subandri }\end{array}$ & - & $\sqrt{ }$ & $\sqrt{ }$ & $\sqrt{ }$ & $\sqrt{ }$ \\
\hline
\end{tabular}

Sumber : Hasil Penelitian Yang Diolah

\section{Upaya Penanggulangan Tindak Pidana Pengalihan Objek Jaminan Fidusia Kota Jambi}

1. Upaya Preventif (Pencegahan Secara Umum)

Menurut Fajar Kuncoro, menerangkan bahwa:

Setiap tahunnya pihak kepolisian ikut berperan dalam upaya pencegahan terjadinya tindak pidana pengalihan objek jaminan fidusia. Upaya pencegahannya yaitu dengan mengundang pihak-pihak perusahaan pembiyaan konsumen berupa sosialisasi dengan bekerjasama dengan Otoritas Jasa Keuangan (OJK) dan Kanwil Kemenkumham untuk mendaftarkan objek jaminan fidusia agar mendapat perlindungan hukum jika suatu saat terjadi tindak pidana.

Sedangkan di PT. ACC sendiri menurut Dova Kalanik ada beberapa hal yang perlu dilakukan untuk menanggulangi tindak pidana pengalihan objek jaminan fidusia adalah sebagai berikut:

a. Ditingkatkannya pengawasan terhadap konsumen yang sering menunggak pembayaran kredit. Apabila telah sering menunggak maka harus lebih diawasi keberadaan kendaraan roda empat dan apabila sudah menungak 3 (tiga) bulan maka pada tanggal jatuh tempo tiga bulan langsung dilakukan eksekusi kendaraan roda empat sehingga dapat memperkecil kemungkinan kendaraan roda empat berpindah ke pihak lain.

b. Meningkatkan jumlah eksekutor yang melakukan pengejaran terhadap pelaku maupun kendaraan roda empat yang digelapkan ke luar daerah sehingga pencapaian target mengeksekusi aset perusahaan dapat terpenuhi. 
c. Mendaftarkan dan membuat akta jaminan fidusia ke kantor pendaftaran fidusia agar jika terjadi suatu masalah dikemudian hari pihak perusahaan mendapatkan perlindungan hukum.

d. Bekerja sama dengan pihak terkait (kepolisian) sebagai aparat penegak hukum dengan memberikan penyuluhan mengenai kesadaran hukum masyarakat, sehingga masyarakat dapat memahami hak-hak dan kewajibannya sebagai anggota masyarakat. Hal ini dapat dilakukan dalam bentuk ceramah-ceramah, temu wicara, diskusi dan lain-lain.

Berdasarkan uraian di atas menurut penulis pihak PT. ACC Kota Jambi bekerjasama dengan pihak kepolisian melakukan upaya preventif dalam menanggulangi Tindak Pidana pidana pengalihan objek jaminan fidusia. Menurut penulis hendaknya Lembaga Pembiayaan Konsumen lebih ketat dalam melakukan pengawasan terhadap objek jaminan fidusia.

2. Upaya Represif

Menurut Yura selaku Collector PT. Astra Credit Companies Kota Jambi mengatakan bahwa Jika debitur melakukan tindak pidana tersebut maka kami akan melakukan beberapa tindakan, pertama kami akan melakukan pendekatan secara humanis terlebih dahulu agar kedua belah pihak saling diuntungkan, kemudian jika debitur tersebut tidak kooperatif maka kami akan memberikan surat peringatan 1 sampai 3 kali dan melakukan somasi. Jika dalam waktu satu bulan debitur tidak menunjukan itikad baik maka kami akan melakukan eksekusi sesuai dengan akta jaminan fidusia tadi, tapi jika objek jaminan fidusia itu hilang maka kami akan membawanya ke jalur hukum pidana dengan melaporkannya ke aparat penegak hukum dalam hal ini pihak kepolisian.

Langkah-langkah yang dilakukan oleh pihak Polresta Jambi dalam upaya tindak pidana pengalihan objek jaminan fidusia di Kota Jambi tidak jauh berbeda dengan apa yang dilakukan oleh pihak Polda Jambi hanya saja ruang lingkup Polresta Jambi lebih spesifik di daerah Kota Jambi atau ruang lingkup Kota Jambi.

Menurut Fajar Kuncoro, menerangkan bahwa paya represifnya yaitu, pertama, menerima laporan ketika adanya laporan tindak pidana fidusia tersebut. Kedua, berusaha mencari jalan terbaik dengan mendamaikan kedua belah pihak melalui mediasi penal (keadilan restoratif) agar kedua belah pihak mendapatkan hasil yang saling menguntungkan.

Tindakan terhadap seseorang yang melakukan tindak pidana Pasal pengalihan objek jaminan Fidusia yaitu berupa hukuman, dengan cara melaporkan pelaku yang melakukan tindak pidana pengalihan objek jaminan fidusia sehingga dapat diproses dan diberikan hukuman yang setimpal maka hal ini juga merupakan pencegahan terhadap orang lain yang mungkin akan melakukan penggelapan agar tidak melakukannya karena akibatnya akan dihukum. Namun dalam usaha represif ini perlu diperhatikan dengan baik sebelum memberikan hukuman.

Dengan demikian seorang penegak hukum harus mengetahui tentang kriminologi, faktor apa yang membuat seseorang melakukan tindak pidana pengalihan objek jaminan fidusia bagaimana ia melakukan tindak pidana tersebut itu dan siapa yang melakukan tindakan tersebut. Dalam hal inilah 
penting sekali peranan kriminologi bagi para penegak hukum, dimana dengan mengetahui keadaan si pelaku (dader) maka seorang hakim dapat menjatuhkan hukuman yang paling tepat terhadap seseorang yang melakukan kejahatan.

Perbuatan pengalihan barang jaminan kepada pihak ketiga tidak boleh dilakukan oleh seorang debitur dengan jalan apapun tanpa persetujuan tertulis terlebih dahulu dari kreditur. Apabila hal tersebut terjadi, maka seluruh utang debitur kepada kreditur dapat ditagih secara seketika dan sekaligus, tanpa pemberitahuan secara tertulis terlebih dahulu oleh kreditur kepada debitur. Tindakan debitur tersebut dapat dikatakan penggelapan sebagaimana yang diatur dalam Pasal 372 KUHPidana dengan ancaman penjara selama-lamanya 4 tahun. Berbeda dengan Pasal 23 Ayat (2) UndangUndang Jaminan Fidusia menyatakan bahwa pemberi fidusia dilarang pengalihan, menggadaikan dan menyewakan objek yang menjadi jamin kepada pihak lain kecuali dengan adanya persetujuan tertulis dari penerima fidusia.

Apabila ketentuan tersebut dilanggar, maka berdasarkan Pasal 36 Undang- Undang Jaminan Fidusia, pemberi fidusia dapat dipidana dengan pidana penjara paling lama 2 tahun dan denda paling banyak Rp.50.000.000,(lima puluh juta Rupiah).

Pengalihan jaminan fidusia telah diatur dalam Pasal 19 Undang-Undang Jaminan Fidusia, yang isinya "pengalihan hak atas piutang yang dijamin dengan fidusia mengakibatkan beralihnya demi hukum segala hak dan kewajiban penerima fidusia kepada kreditor baru". Beralihnya jaminan fidusia didaftarkan oleh kreditor baru kepada Kantor Pendaftaran Fidusia.

Menurut Yura adapun kendala yang dihadapi dalam menanggulangi kasus ini bahwa pertama ketidak koperatifan debitur dalam kasus ini, kedua jika kasus ini dipidanakan dan naik ke pengadilan maka perusahaan tidak mendapatkan apa-apa dan menjadi rugi, oleh karena itu pihak perusahaan lebih mengedepankan perdamaian agar perusahaan tidak merugi.

Menurut Fajar Kuncoro mengatakan bahwa "pihak leasing lebih mengutamakan perdamaian dengan pelaku tindak pidana tehadap penggelapanobjek jaminan fidusia ini, dari data tahun kemarin 2019 didapatkan hanya satu kasus yang sampai ke tahap pengadilan dan di eksekusi di Lapas kelas II A Jambi".

Berdasarkan uraian di atas menurut penulis pihak korban dalam hal ini PT. Astra Credit Companies Kota Jambi dalam menangani kasus ini lebih mengutamakan perdamaian agar kedua pihak saling diuntungkan sedangkan pidana adalah jalan terakhir untuk menyelesaikan masalah ini.

\section{SIMPULAN}

Faktor-faktor penyebab terjadinya tindak pidana pengalihan objek jaminan fidusia di Kota Jambi terdiri atas faktor intern yaitu faktor kurangnya kesadaran dalam diri pelaku, pelaku yang terkesan mengabaikan isi perjanjian jaminan fidusia, dan faktor ekstern yaitu tekanan ekonomi, faktor lingkungan (penadah), kurangnya pengawasan dari pihak korban. 
Upaya penanggulangan penyebab terjadinya tindak pidana pengalihan objek jaminan fidusia di Kota Jambi adalah dengan preventif dari pihak kepolisian yaitu melakukan sosialisasi kepada pihak pembiayaan konsumen untuk mendaftarkan objek jaminan fidusia bekerjasama dengan Otoritas Jasa Keuangan dan Kanwil Kemenkumham kemudian dari pihak korban yaitu ditingkatkan pengawasan terhadap konsumen yang menunggak, menambah jumlah eksekutor, mendaftarkan dan membuat akta jaminan fidusia, bekerjasama dengan pihak kepolisian untuk melakukan sosialisasi kemasyarakat. Sedangkan upaya represif yang dilakukan Polresta Jambi yaitu Menerima laporan dan berusaha mencari jalan terbaik dengan keadilan restoratif dan upaya represif dari pihak korban yaitu Melakukan beberapa tindakan dari SP 1 sampe SP 3 dan somasi. Jika tidak ada kata sepakat maka berlanjut ke jalur hukum.

\section{DAFTAR PUSTAKA}

\section{Dokumen Hukum}

Republik Indonesia. Undang-Undang Nomor Undang-Undang Nomor 42 Tahun 1999 Tentang Jaminan Fidusia.

\section{Buku}

Ali, Achmad. Menguak Teori Hukum (Legal Theory) dan Teori Peradilan (Judicialprudence) Termasuk Iterpretasi Undang-Undang (legisprudence), Kencana Prenada Media Group, Jakarta, 2009.

Arief, Barda Nawawi. Beberapa Aspek Kebijkan Penegakan Dan Pengembangan Hukum Pidana, Citra Aditya Bakti, Bandung, 1998.

Atmasasmita, Romli. Teori dan Kapita Selekta Kriminologi, Eresco, Bandung, 1992.

Dirdjosisworo, Soedjono. Sosio Kriminologi, Sinar Baru, Bandung, 1984.

Hasoeprapto, Hartono. Pengantar Tata Hukum Indonesia, Liberty, Yogyakarta, 1998.

Kusuma, Mulyana W. Kejahatan dan Penjahat, Alumni, Bandung

Mertokusumo, Sudikno. Mengenal Hukum (Suatu Pengantar), Liberty, Yogyakarta, 1999.

Prakoso, Abintoro. Kriminologi dan Hukum Pidana, Laksbang PRESSindo, Yogyakarta, 2017.

Rachmat,Budi. Multi Finance Handbook, PradyaParamita, Jakarta, 2004.

Riswandi, Budi Agus. Aspek Hukum Banking, Raja Grafindo Perada, Jakarta, 2005.

Simorangkir, O.P. Lembaga Keuangan Bank dan Non bank, Ghalia Indonesia, Bogor, 2004.

Soekanto, Soerjono. Kriminologi SuatuPengantar, Ghalia Indonesia, Jakarta, 1986.

Wantu, Fence M. Kepastian Hukum Keadilan dan Kemanfaatan, Pustaka Pelajar, Yogyakarta, 2011. 
Wijaya, Farid. Pengkreditan Bank dan Lembaga-lembaga Keuangan Kita, Yogyakarta, 1991.

Yurizal, Aspek Pidana dalam Undang-Undang No.42 Tahun 1999 Tentang Jaminan Fidusia, Media Nusa Creative, Malang, 2015.

Jurnal/ Majalah Ilmiah

Hafrida. Kebijakan Hukum Pidana Terhadap Pengguna Narkotika Sebagai Korban Bukan Pelak Tindak Pidana. PJIH 3, 1, (2016).

Lasmadi, Sahuri dan Sudarti, Elly. Penyuluhan Hukum Tentang Merugikan Keuangan Negara Kepada Kepala Desa Se Kecamatan Pemayung Kabupaten BatangHari Guna Pencegahan Korupsi Pada pemerintahan Desa. Jurnal Karya Abadi Masyarakat, Volume 3, Nomor 2, 2019.

Rahayu, Sri dan Wahyudhi, Dheny. Penegakan Hukum Ketentuan Pidana Pasal 158 Undang-Undang Nomor 4 Tahun 2009 Tentang Pertambangan Mineral dan Batubara Terhadap Kegiatan Pertambangan TanpaIzin di Kabupaten Muaro Jambi. INOVATIF Jurnal Ilmu Hukum, 2013.

Usman. Analisis Perkembangan Hukum Pidana. Jurnal Ilmu Hukum Jambi. 